\title{
Inquiry/Discovery-Based Instruction to Improve Critical Thinking Skills and Mastery of Physics Concepts
}

\author{
C. Huda, S.D. Aji, M.N. Hudha, F. Gamat, \& Wartono \\ Universitas Kanjuruhan Malang, Malang, Indonesia
}

\begin{abstract}
Inquiry/discovery-based instruction is a teaching model that enables students actively and independently discover and acquire their knowledge. The role of the teacher is only as a facilitator that guides them to discover and solve the problems they encounter. Using one group pretest and postest design, the present study was aimed to find out the effectiveness of inquiry/discovery-based teaching to improve high school students' critical thinking skills and mastery of physics concepts. An effect size was used to measure the effectiveness of the inquiry/discovery-based instruction. Moreover, the improvement of critical thinking skills and mastery of physics concepts was seen from an N-Gain analysis using a two-way MANOVA statistical test. The result of the study showed that inquiry/discovery-based instruction was effective in improving critical thinking skills and students' mastery of physics concepts during the discovery process in conducting an experiment.
\end{abstract}

Keywords- Instruction, Thinking Skills; Mastery of Physics Concepts

\section{INTRODUCTION}

Critical thinking skills play an important role in improving the mastery of physics concepts. Students will understand physics concepts when the learning process is meaningful [4]. A meaningful learning can develop students' critical thinking skills [7].

Inquiry/discovery-based instruction is one of the ways to improve critical thinking skills [5,9]. It is a teaching and learning process that encourages students to search for new information and investigate it systematically, critically, logically, and analytically so that they can confidently formulate their own discovery [2].

Using this teaching model, it is expected that [10,8], 1) students will understand the basic concepts better, 2) students are encouraged to think and work on their own initiative [3], 3 ) students are encouraged to think inclusively and formulate their own hypotheses. Inquiry-based instruction that develops critical thinking can improve students' achievement in learning science (Qing, Jing, \& Yan, 2010) and concept mastery (Sriarunrasmee et al., 2015) $[6,8]$.

\section{METHOD}

The present research used one group pretest and posttest design. The data were analyzed using a MANOVA statistical test. The samples were 35 out of 107 tenth-grade students in the $2015 / 2016$ school year.

The data of critical thinking skills were collected through a pretest and posttest whose questions were of the open-ended essay. The critical thinking skills were measured using the instrument outlined in Table 1. The mastery of physics concepts was measured using a multiple choice test.

TABLE I. STUDENT'S CRITICAL THINKING INDICATORS

\begin{tabular}{|c|c|}
\hline $\begin{array}{c}\text { Critical } \\
\text { Thinking Indicators }\end{array}$ & $\begin{array}{l}\text { Critical Thinking } \\
\text { Descriptors }\end{array}$ \\
\hline 1. Problem formulation & $\begin{array}{l}\text { - Formulating questions that lead to } \\
\text { the investigation of the answer }\end{array}$ \\
\hline 2. Conveying arguments & $\begin{array}{l}\text { - Relevant arguments } \\
\text { - Demonstrating the similarities and } \\
\text { differences } \\
\text { - Complete argument }\end{array}$ \\
\hline 3. Deduction & $\begin{array}{l}\text { - Logical Deduction } \\
\text { - Interpreting accurately }\end{array}$ \\
\hline 4. Induction & $\begin{array}{l}\text { - Analyzing the data } \\
\text { - Making generalizations }\end{array}$ \\
\hline 5. Doing evaluations & $\begin{array}{l}\text { - Drawing conclusions } \\
\text { - Evaluating based on facts }\end{array}$ \\
\hline $\begin{array}{l}\text { 6. Making decisions and tak- } \\
\text { ing actions }\end{array}$ & $\begin{array}{l}\text { - Giving alternatives } \\
\text { - Determining a way out } \\
\text { - Choosing the probability }\end{array}$ \\
\hline
\end{tabular}

(Ennis. R.H.. 1985)

Content and construct validity test was carried out prior to piloting the test items. Afterwards, the test item validity and reliability test were conducted. The improvement of critical thinking skills and physics concept mastery was seen from the gain score. And Becker's effect size was used to find out the effectiveness of the implementation inquiry/ discovery-based instruction to improve critical thinking skills and physics concept mastery. 


$$
E S=\left(\frac{\text { meanpost }- \text { meanpre }}{\text { standartdeviation }}\right)
$$

The effect size coefficient criteria are outlined as follows:

TABLE II. EFFECT SIZE CRITERIA

\begin{tabular}{|l|l|}
\hline \multicolumn{1}{|c|}{ Interval Coefficient } & \multicolumn{1}{c|}{ Criteria } \\
\hline $\mathrm{ES} \leq 0.2$ & ES-Low \\
\hline $0.2<\mathrm{ES} \leq 0.8$ & ES-Moderate \\
\hline $\mathrm{ES}>0.30$ & ES-Low \\
\hline
\end{tabular}

\section{RESULTS AND DISCUSSION}

The pretest and posttest data revealed that students' critical thinking about hydrostatic pressure improved. The gain score was 0.602 . In other words, the improvement of students' critical thinking skills could be categorized as g-moderate.

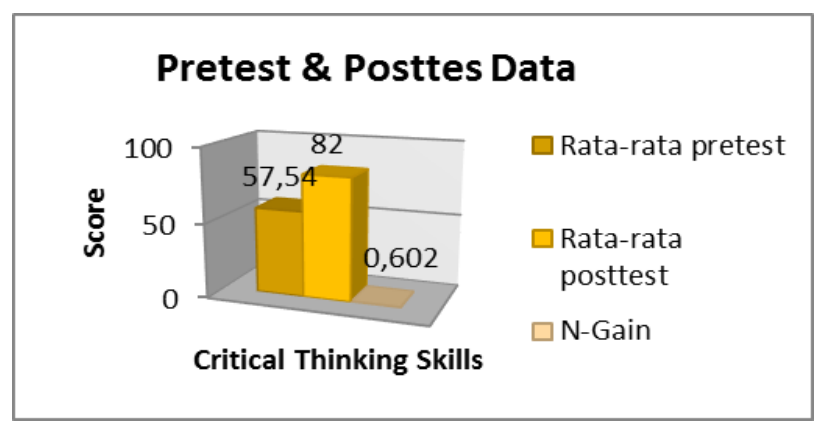

Fig 1. Pretest and posttest data of critical thinking skills

Based on Figure 1, the inquiry/discovery-based instruction improved the critical thinking skills of the tenth graders at Nasional Malang Senior High School. The improvement was formulated as follows:

$$
E S=\left(\frac{\text { meanpost }- \text { meanpre }}{\text { standartdeviation }}\right)=1,713
$$

The effect size score was high. Thus, it can be concluded that the inquiry/discovery-based instruction was effective in improving the critical thinking skills.

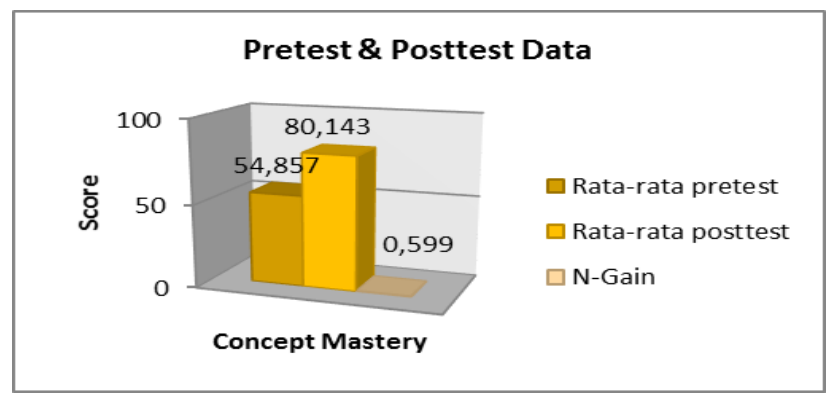

Fig 2. Pretest and posttest data of student concept mastery
Based on Figure 2, the inquiry/discovery-based instruction improved the concept mastery of the tenth graders at Nasional Malang Senior High School. The effectiveness of he inquiry/discovery-based instruction is formulated as follows:

$$
E S=\left(\frac{\text { meanpost }- \text { meanpre }}{\text { standartdeviation }}\right)=1,624
$$

The effect size score was high. Thus, it can be concluded that the inquiry/discovery-based instruction was effective in improving student concept mastery.

The inquiry/discovery-based instruction significantly improved critical thinking skills when students solved problems in an experiment [3]. The students were indirectly trained to find, find and solve problems using their independent thinking. The inquiry/discovery-based instruction is different from other teaching models that emphasize knowledge enrichment, resulting in learning is a process of imitation.

Inquiry/discovery-based instruction trains students to develop facts, construct concepts and draw general conclusions about phenomena they encounter through observation, investigation, experiments, comparing each other's discovery, posing questions and seeking for the answers to his own questions. Therefore, this model is effective to improve concept mastery.

\section{CONCLUSION}

The result of the study shows that inquiry/discovery-based instruction improved students' critical thinking skills and mastery of physics concepts during the discovery process in conducting an experiment.

\section{REFERENCES}

[1] R.H. Ennis, A Logical Basis for Measuring Critical Thinking Skills, Association for Supervision and Curriculum Development, 1985.

[2] S.A. Forawi, Standard-based science education and critical thinking. Thinking Skills and Creativity. https://doi.org/10.1016/j.tsc.2016.02.005, 2016.

[3] K. Green, \& C. Jax. Problem solvers are better leaders: facilitating critical thinking among educators through online education ., 15, 727730. https://doi.org/10.1016/j.sbspro.2011.03.173. 2011.

[4] M. N. Hudha, L. Yuliati, \& Sutopo, Volume 6 No. 1 January 2016, Jurnal Inspirasi Pendidikan, 6(1), 733-743, 2016.

[5] A. Kasmurie, A. Kitot, A. Razak, \& A. Ali. The Effectiveness of Inquiry Teaching in Enhancing Students 'Critical Thinking, 7(C), 264-273. https://doi.org/10.1016/j.sbspro.2010.10.037. 2010.

[6] Z. Qing, G. Jing, \& W. Yan, Promoting preservice teachers , critical thinking skills by inquiry-based chemical experiment, 2, 4597-4603. https://doi.org/10.1016/j.sbspro.2010.03.737. 2010.

[7] V. Smetanová, \& A. Drbalová, Veronika Smetanová, 171, 724-732. https://doi.org/10.1016/j.sbspro.2015.01.184, 2015.

[8] J. Sriarunrasmee, P. Suwannatthachote, \& P. Dachakupt, Virtual Field Trips with Inquiry learning and Critical Thinking Process : A Learning Model to Enhance Students ' Science Learning Outcomes, Procedia - 
Social and Behavioral Sciences, 197(February), 1721-1726. https://doi.org/10.1016/j.sbspro.2015.07.226, 2015.

[9] M.Tate, English for Special fi c Purposes Critical thinking and discovering the meaning of unfamiliar terms through the word part analysis strategy: A study of Iranian medical students, English for Specific Purposes, 40, 1-10. https://doi.org/10.1016/j.esp.2015.05.001, 2015.

[10] P. Thaiposri, \& P. Wannapiroon, Enhancing students ' critical thinking skills through teaching and learning by inquiry-based learning activities using the social network and cloud computing, Procedia - Social and

Behavioral Sciences,
https://doi.org/10.1016/j.sbspro.2015.02.013, 2015. 